\title{
Ibadah Sebagai Aspek Ritual Ummat Islam
}

Nasuha Nasuha ${ }^{1}$, Muh Fadli Fajrin ${ }^{2}$, Muhammad Arsyam ${ }^{3}$

${ }^{1}$ Sekolah Tinggi Agama Islam (STAI) Darud Dakwah Wal-Irsyad (DDI) Kota Makassar, Indonesia Email: nasuha2801@gmail.com

${ }^{2}$ Sekolah Tinggi Agama Islam (STAI) Darud Dakwah Wal-Irsyad (DDI) Kota Makassar, Indonesia Email: muhfadlifajrin1234@gmail.com

${ }^{3}$ Sekolah Tinggi Agama Islam (STAI) Darud Dakwah Wal-Irsyad (DDI) Kota Makassar, Indonesia Email: arsyam0505@gmail.com

\begin{abstract}
Abstrak
Hampir semua masyarakat yang melakukan ritual keagamaan dilatarbelakangi oleh kepercayaan. Adanya kepercayaan pada yang sakral, menimbulkan ritual. Oleh karena itu, ritual didefinisikan sebagai perilaku yang diatur secara ketat. Dilakukan sesuai dengan ketentuan, yang berbeda dengan perilaku sehari-hari, baik cara melakukannya maupun maknanya. Apabila dilakukan seuai dengan ketentuan, ritual diyakini akan mendatangkan keberkahan, karena percaya akan hadirnya sesuatu yang sakral.
\end{abstract}

\section{Kata Kunci : Ibadah, Aspek Ritual, Ummat Islam}

\section{A. PENDAHULUAN}

Prinsip dasar dari semua agama mengenal dengan istilah ritual, karena setiap agama memiliki ajaran tentang hal yang sakral. Salah satu tujuan pelaksanaan ritual adalah pemeliharaan dan pelestarian kesakralan. Disamping itu ritual merupakan tindakan yang memperkokoh hubungan pelaku dengan objek yang suci, dan memperkuat solidaritas kelompok yang menimbulkan rasa aman dan kuat mental.

Sebagian dari manusia itu sendiri yang menganggap ibadah itu hanyalah sekedar menjalankan rutinitas dari hal-hal yang dianggap kewajiban, seperti sholat dan puasa. Sayangnya, kita lupa bahwa ibadah tidak mungkin lepas dari pencapaian kepada Tauhid terlebih dahulu. Mengapa? keduanya berkaitan erat, karena mustahil kita mencapai tauhid tanpa memahami konsep ibadah dengan sebenar-benarnya.

Adapun pendapat dari Syaikhul Islam Ibnu Taimiyah Rahimahullah mengatakan bahwa: "Ibadah adalah suatu istilah yang mencakup segala sesuatu yang dicintai Allah dan diridhai-Nya, baik berupa perkataan maupun perbuatan, yang tersembunyi (batin) maupun yang nampak (lahir).

Dari definisi singkat tersebut, maka secara umum ibadah seperti yang kita ketahui di antaranya yaitu mendirikan shalat, menunaikan zakat, berpuasa pada bulan ramadhan (maupun puasa-puasa sunnah lainnya), dan melaksanakan haji. Selain ibadah pokok tersebut, hal-hal yang sering kita anggap sepele pun sebenarnya bernilai ibadah dan pahalanya tidak dapat diremehkan begitu saja

\footnotetext{
1,2 Mahasiswa

${ }^{3}$ Dosen Pembimbing
} 


\section{B. PEMBAHASAN}

\section{Pengertian Ibadah}

Pengettian ibadah secara bahasa adalah tunduk atau merendahkan diri. Sedangkan secara istilah atau syara', ibadah merupakan suatu ketaatan yang dilakukan dan dilaksanakan sesuai perintah-Nya, merendahkan diri kepada Allah SWT dengan kecintaan yang sangat tinggi dan mencakup atas segala apa yang Allah ridhai baik yang berupa ucapan atau perkataan maupun perbuatan yang dhahir ataupun bathin.

Pada dasarnya ibadah dapat di bagi dalam tiga kategori utama antara lain:

1) Ibadah hati (qalbiah) adalah ketika seseorang telah memiliki rasa takut, rasa cinta (mahabbah), mengharap (raja'), senang (raghbah), ikhlas, tawakkal.

2) Ibadah lisan \& hati (lisaniyah wa qalbiyah) adalah dalam bentuk dzikir, tasbih, tahlil, tahmid, takbir, syukur, berdoa, membaca ayat Al-qur'an.

3) Ibadah perbuatan fisik dan hati (badaniyah wa qalbiyah) adalah yang dilaksanakan dalam bentuk sholat, zakat, haji, berjihad, berpuasa.

Adapun pengertian Ibadah secara istilah (terminologi) adalah penghambaan seorang manusia kepada Allah untuk dapat mendekatkan diri kepada-Nya sebagai realisasi dari pelaksanaan tugas hidup selaku makhluk yang diciptakan Allah.

Selanjutnya pengertian ibadah secara bahasa (etomologis) berasal dari bahasa Arab dengan asal kata 'abada, ya'budu, 'abdan, fahuwa 'aabidun. 'Abid, berarti hamba atau budak, yakni seseorang yang tidak memiliki apa-apa, hatta dirinya sendiri milik tuannya, sehingga karenanya seluruh aktifitas hidup hamba hanya untuk memperoleh keridhaan tuannya dan menghindarkan murkanya.

Keberadaan manusia di ciptakan muka bumi ini adalah adalah hamba Allah "Ibaadullaah" jiwa raga haya milik Allah, hidup matinya di tangan Allah, rizki miskin kayanya ketentuan Allah, dan diciptakan hanya untuk ibadah atau menghamba kepada-Nya.

Sebagaimana disebutkan dalam al-Qur'an pada surah al-Dzariyat ayat 56 :

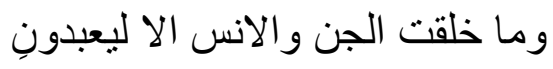

Terjemahannya:

"Tidak Aku ciptakan Jin dan Manusia kecuali hanya untuk beribadah kepada-Ku" (QS. al-Dzariyat: 56). 
Pembagian ibadah dalam ajaran agama Islam berdasarkan jenisnya dapat di bagi dalam dua hal antara lain adalah:

a) Ibadah Mahdah

Ibadah Mahdah adalah penghambaan yang murni hanya hubungan hamba dengan Allah. Ibadah Mahdah memiliki 4 prinsip :

1) Keberadaannya harus berdasarkan adanya dalil perintah yang berdasarkan baik dari Al-Quran maupun Al-Sunnnah. Jadi merupakan otoritas wahyu, tidak boleh ditetapkan oleh akal atau logika keberadaannya. Tata caranya harus berpola kepada contoh dari Rasulullah Muhammad SWA, salah satu tujuan diutus Rasul oleh Allah adalah untuk memberikan contoh dalam alQur;an yang berbunyi :

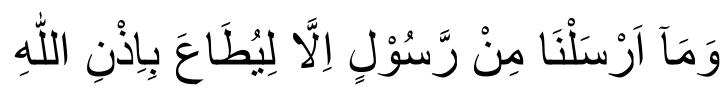

Terjemahannya:

"Dan Kami tidak mengutus seorang Rasul kecuali untuk ditaati dengan izin Allah" (QS. An-Nisa Ayat 64)

2) Bersifat supra rasional (diatas jangkauan akal) Yang berarti ibadah bentuk ini bukan ukuran logika, karena bukan wilayah akal, melainkan wilayah wahyu. Akal hanya berfungsi memahami rahasia dibaliknya yang disebut hikmah at-tasyri.

3) Azasnya "taat" yang dituntut dari hamba dalam melaksanakan ibadah ini adalah kepatuhan atau ketaan.

4) Hamba wajib meyakini bahwa apa yang diperintahkan Allah, semata untuk kebahagiaan hamba, bukan untuk Allah, dan salag satu misi utama diutus Rasul adalah untuk dipatuhi.

b) Ibadah Ghairu Mahdah (tidak murni semata hubungan dengan Allah)

Pengertian dari ibadah ghairu mahdhah ialah segala amalan yang diizinkan oleh Allah yang tata cara dan perincian-perinciannya tidak ditetapkan dengan jelas. Dengan prinsip: Keberadaannya didasarkan atas tidak adanya dalil yang melarang, selama Allah dan Rasul-Nya tidak melarang maka ibadah bentuk ini boleh dilakukan.

Tata laksananya tidak perlu berpola kepada contoh Rasulullah sehingga perkara baru (bid'ah) dalam ibadah ghairu mahdhah diperbolehkan. Bersifat rasional, ibadah bentuk ini baik-buruknya, atau untung-ruginya, manfaat atau mudharatnya, dapat ditentukan oleh akal atau logika. Sehingga jika menurut 
logika sehat, itu buruk, merugikan dan mudharat, maka tidak boleh dilaksanakan. Azasnya Manfaat, selama itu bermanfaat maka boleh dilakukan.

Oleh karena itu dalam ibadah ghairu mahdhah, jangan bertanya mana dalil yang memerintahkannya. Tapi tanyakan dalil mana yang melarangnya?Dalam Ibadah ini berlaku kaidah ushul fiqih :

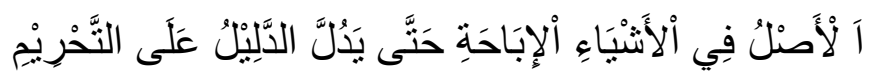

Artinya:

"Pada dasarnyasegala sesuatu itu hukumnya diperbolehkan sepanjang tidak ada dalil yang menunjukkan keharamannyasegala sesuatu itu hukumnya diperbolehkan sepanjang tidak ada dalil yang menunjukkan keharamannya"

Adapun contoh ibadah ghairu mahdhah antara lain: Masalah-masalah furu, seperti shalat subuh dengan qunut atau tidak, dzikir, dakwah, tolong menolong dll. Jika dalam ibadah mahdhah yang bersifat ta'abbudi tidak boleh ada improvisasi, maka dalam ibadah ghairu mahdhah ini justru terbuka lebar terhadap inovasi. Tidak ada bid'ah (kullu bid'atin dlalalah) dalam ibadah ghairu mahdhah.

\section{Pengertian Ritual}

Pengertian ritual secara harfiah adalah sebagai suatu kegiatan yang dilakukan oleh sekelompok orang atau perorangan dengan tata cara tertentu. Dalam ilmu sosiologi kata ritual berarti bahwa aturan-aturan tertentu yang digunakan dalam pelaksanaan agama yang melambangkan ajaran dan yang mengingatkan manusia pada ajaran tersebut.

Begitupala dalam ilmu antropologi agama, kata ritul adalah sebagai perilaku tertentu yang bersifat formal, dilakukan dalam waktu tertentu secara berkala, bukan sekedar sebagai rutinitas yang bersifat teknis, melainkan menunjuk pada tindakan yang didasari oleh keyakinan religius terhadap kekuasaan atau kekuatan-kekuatan mistis.

Berdasarkan dalam Kamus Besar Bahasa Indonesia, mengatakan arti ritual yakni hal ihwal ritus atau tata cara dalam upacara keagamaan. Upacara ritual atau ceremony adalah sistem atau rangkaian tindakan yang ditata oleh adat atau hukum yang berlaku dalam masyarakat yang berhubungan dengan berbagai macam peristiwa yang biasanya terjadi dalam masyarakat yang bersangkutan.

Pengertian ritual secara umum adalah "segala bentuk atau metode tertentu dalam melakukan upacara keagamaan atau upacara penting atau tatacara dalam 
bentuk upacara. Makna dasar ini menyiratkan bahwa, disatu sisi aktivitas ritual berbeda dari aktifitas biasa, terlepas dari ada tidaknya nuansa keagamaan atau kekhidmatan.

Maka dari beberapa penjelasan pengertian ritual di atas dapat disimpulkan bahawa kata ritual adalah serangkaian tindakan yang dilakukan terutama untuk nilai simbolis mereka. Karena hal demikian ini sudah menjadi tradisi masyarakat, termasuk oleh komunitas agama dan adat tertentu. Adapun tujuan ritual tersebut bervariasi. Acara ritual dapat memenuhi kewajiban agama atau cita-cita, memenuhi kebutuhan spiritual atau emosional, memperkuat ikatan sosial, menyediakan pendidikan sosial dan moral, menunjukkan rasa hormat atau penyerahan, memungkinkan seseorang untuk menyatakan afiliasi seseorang, mendapatkan penerimaan sosial atau persetujuan untuk beberapa event- atau ritual yang kadangkadang dilakukan hanya untuk kesenangan ritual itu sendiri.

Adapaun dari segi tujuan ritual itu sendiri dapat dibagi menjadi tiga bagian penting antara lain:

a. Bertujuan untuk bersyukur kepada Tuhan

b. Bertujuan untuk mendekatkan diri kepada Tuhan agar mendapatkan keselamatan dan rahmat,

c. Bertujuan untuk meminta ampun atas kesalahan yang dilakukan.

Selanjutnya ritual dapat bedakan dari segi jangkauannya yakni; 1) Ritual sebagai teknologi, seperti upacara yang berhubungan dengan kegiatan pertanian dan perburuan. 2) Ritual sebagai terapi, seperti upacara untuk mengobati dan mencegah hal-hal yang tidak diinginkan. 3) Ritual sebagai ideologis -mitos dan ritual tergabung untuk mengendalikan suasana perasaan hati, perilaku, sentimen, dan nilai untuk kelompok yang baik. Contohnya, upacara inisiasi yang merupakan konfirmasi kelompok terhadap status, hak, dan tanggung jawab yang baru. 4) Ritual sebagai penyelamatan (salvation), misalnya seseorang yang mempunyai pengalaman mistikal, seolah-olah menjadi orang baru; ia berhubungan dengan kosmos yang juga mempengaruhi hubungan dengan dunia profan. 5) Ritual sebagai revitalisasi (penguatan atau penghidupan kembali). Ritual ini sama dengan ritual salvation yang bertujuan untuk penyelamatan tetapi fokusnya masyarakat.

Ritual di tinjau dari tingkatannya dapat dibedakan menjadi; 1) Ritual Islam yang primer adalah ritual yang wajib dilakukan oleh umat islam. Umpamanya, 
shalat wajib lima waktu dalam sehari semalam. Kewajiban ni disepakati oleh para ulama karena berdasarkan ayat al-Qur'an dan hadist Nadi Muhammad Saw. 2) Ritual islam yang skunder adalah ibadah shalat sunnah, umpamanya bacaan dalam rukuk dan sujud, shalat berjama'ah, shalat tahajjud, dan shalat dhuha. 3) Ritual islam teritier adalah ritual yang berupa anjuran dan tidak sampai pada derajat sunnah. Umpamanya, dalam hadist yang diriwayatkan oleh imam Al-Nasa'i dan Ibnu Hibban yang menyatakan bahwa Nabi Muhammad saw bersabda, “orang membaca ayat kursiy setelah shalat wajib, tidak tidak akan ada yang menghalanginya untuk mauk syurga. Meakipun ada hadist tersebut, ulama tidak berpendapat bahwa bacaan ayat kursiy setelah shalat wajib adalah sunnah. Karena itu, membaca ayat kursiy setelah shalat wajib hanya bersifat tahsini.

\section{Kewajiban Ibadah Bagi Manusia}

Manusia adalah salah satu dari makhluk Allah swt. di samping memiliki sejumlah kekurangan, manusia memiliki suatu kelebihan, berupa potensi berkembang, potensi membangun peradaban dan kebudayaannya, karena padanya ia dianugerahi "akal." Manusia diciptakan oleh Allah swt. sebagai 'abid' dan sebagai khalifah- Nya di atas bumi. Sebagai 'abid', manusia diharuskan untuk tunduk dan patuh hanya kepada Allah swt., mengandung arti bahwa keseluruhan jiwa dan aktifitas manusia haruslah sejalan dengan izin dan perintah Allah swt.

Sebagai khalifah Allah, manusia memiliki dua fungsi utama, yaitu fungsi kepemimpinan, yaitu Jabatan Formal dan Fungsi Kepribadian Muslim. Bagi yang mendapat amanah Jabatan Formal, ia harus menjalankan amanah Allah dalam wujud merealisasikan hukum-hukum Allah, menerapkan keadilan, kebenaran dan melindungi seluruh masyarakat dan wilayah yang dipimpinnya.

Fungsi Kepribadian Muslim mewajibkan seluruh muslim tak terkecuali untuk menjaga melestarikan dan mengembangkan kemakmuran di bumi sebagai hajat hidup bagi semua. Kealpaan menjalankan fungsi-fungsi tersebut berarti kealpaan dalam menunaikan amanah Allah di atas bumi, yang sesungguhnya amanah tersebut adalah amanah terpokok yang seharusnya menjadi perhatian utama dalam hidup manusia.

Dalam literatur dakwah Islamiyah, secara umum ditegaskan bahwa tujuan keberadaan manusia adalah untuk beribadah kepada Allah swt. Manusia 
sesungguhnya adalah "Ibadullah." Kata atau term Ibadullah sudah umum dimaknakan dengan "beribadah" kepada Allah. Secara lebih spesifik, pemaknaan ibadullah ini diartikan sebagai ketundukpatuhan sang hamba kepada Allah swt., sekurang-kurangnya sebagaimana terakumulasi pada enam rukun iman dan lima rukun Islam. Di sisi lain, ada pernyataan tugas manusia, yakni sebagai "khalifah" Kata atau istilah. "Khalifah" bila dikaitkan dengan sejarah umat Islam, sudah pasti merujuk kepada model pemerintahan, tepatnya kepala pemerintahan Islam di awalawal pertumbuhannya pasca wafatnya Rasulullah saw.1 Secara umum, dikenal pemerintahan Khilafah Rasyidah dengan empat tokoh, masing-masing: Abu Bakar al-Shiddieq, Umar bin al-Khattab, Utsman bin al-Affan dan Ali bin Abi Thalib

Dewasa ini, ketidakmampuan berbagai negara Islam menjadikan Islam sebagai simbol sekaligus sebagai hukum positif, oleh sejumlah kalangan disebut sebagai penyebab bagi ketidakmampuan para politisi muslim membumikan kemakmuran di bumi Allah swt., justru dituding sebagai biang keladi terjadinya seribu satu praktek-praktek politik yang membuat bangsa dan negara tetap terbelakang, permusuhan yang berkepanjangan dan ujung-ujungnya, rakyatlah yang menderita. Sudah pasti, bahwa para pegiat khilafah mendakwahkan wajibnya umat ini kembali kepada sistem "Khilafah Rasyidah” sebagai satu-satunya alternatif untuk mengembalikan kejayaan Islam dan umat Islam di muka Bumi Allah swt ini.

Dalam kajian Pemikiran Islam Modern, kata atau istilah "khalifah" dimaknai jauh lebih luas dibanding dengan sekedar memaknainya sebagai model atau bentuk pemerintahan sebagaimana yang dikemukakan di atas. Hal ini erat kaitannya dengan dwifungsi manusia di bumi ini menurut Alquran, yakni sebagai "abid" dan sebagai "khalifah" Allah di atas bumi ini. Tulisan ini akan mengkaji dua pertanyaan pokok, yakni bagaimana kedudukan sekaligus tugas manusia sebagai khalifah dan apa konsekuensi dari kealpaan manusia menunaikan tugas tersebut.

Seperti tertera pada judul, kajian ini bersifat teologis dengan titik berat pembahasan dari sudut pandang lingkungan hidup. Untuk mendapatkan bahan yang selanjutnya dikumpulkan, dianalisis dan disajikan secara deskriptif kualitatif, penulis akan merujuk ke naskah-naskah literatur, baik yang berbentuk teks maupun yang didapatkan melalui media online 


\section{Fungsi Ibadah Bagi Umat Manusia}

Sebagai bentuk realisasi bagi manusia yang diberi tanggung jawab oleh

Allah menjadi Khalifah dan Hamba Allah di muka bumi.

a) Sebagai salah satu cara untuk meningkatkan kualitas komunikasi vertical dengan sang khalik.

b) Meningkatkan derajat Manusia dimata Allah SWT.

\section{KESIMPULAN}

Selaku penulis artikel sangat menyadari bahwa tulisan ini masih jauh dari sempurna, akan tetapi selaku manusia biasa tetap berharap dapat menjadi bahan diskusi dan renungan bersama dalam menambah khasanah ilmu pengetahuan kita, maka berdasarkan dari berbagai penjelasan di atas dapat kami simpulkan sebagai berikut:

1. Ibadah adalah menyembah atau menghamba, secara istilah (Tertimologi) ialah penghambaan seorang manusia kepada Allah untuk dapat mendekatkan diri kepadanya sebagai bentuk realisasi dari pelaksanaan tugas hidup selaku makhluk yang diciptakan Allah SWT. Manusia mempunyai kewajiban sebagai mahkluk ciptaan Allah adalah melaksankan ibadah secara total.

2. Ritual adalah serangkaian tindakan yang dilakukan terutama untuk nilai simbolis mereka karena sudah menjadi tradisi bagi aspek kehidupan masyarakat, termasuk oleh komunitas agama dan adat tertentu.

3. Perkembangan ilmu yang begitu pesat di zaman modern atau dengan istilah revolusi industri 4.0 berharap dari aspek nilai-nilai Agama dan Agama dapat dijadikan Arah dalam menentukan perkembangan ilmu selanjutnya. Karena tanpa adanya bimbingan terhadap ilmu agama tersbut di khawatirkan kehebatan ilmu dan teknologi tidak semakin mensejahterakan manusia dan jauh dari prilaku yang Allah telah tetapkan serta malah akan justru merusak bahkan menghancurkan kehidupan umat manusia di muka bumi. 


\section{DAFTAR PUSTAKA}

Wekke, I. S. (2015). Sasi masjid dan adat: praktik konservasi lingkungan masyarakat minoritas muslim Raja Ampat. Al-Tahrir: Jurnal Pemikiran Islam, 15(1), 1-20.

Janna, N. M., a., \& Arsyam, M. (2021, January 14). Makanan Dan Minuman Dalam Islam. https://doi.org/10.31219/osf.io/49us8

Widodo, A. (2020). Nilai budaya ritual perang topat sebagai sumber pembelajaran ips berbasis kearifan lokal di sekolah dasar. Gulawentah: Jurnal Studi Sosial, 5(1), 1.

Mustafa, Z. A. (2019). Ritual Mocera Tasi Masyarakat Wotu di Luwu Timur Perspektif Maslahat (Doctoral dissertation, Universitas Islam Negeri Alauddin Makassar).

Ashar, A. (2019). Metode Program Jumat Ibadah dalam Meningkatkan Kedisiplinan Beribadah bagi Siswa MTS Negeri Gowa Kecamatan Bontomarannu Kabupaten Gowa (Doctoral dissertation, Universitas Islam Negeri Alauddin Makassar).

Arsyam, M. (2020). Manajemen pendidikan islam.

Usman, H. A., Arsyam, M., \& Yusuf, M. (2021, January 17). ETIKA PERDAGANGAN DALAM ISLAM. https://doi.org/10.31219/osf.io/q6rbz

Hadiwaryono, P., 1994, Hakikat Hidup Berkeluarga, dalam Keluarga; Peran dan Tanggungjawabnya di Zaman Moderen, Yogyakarta: Panitian Pameran Buku nasional IKAPI.

Arsyam, M., \& Alwi, A. M. (2020). Konsep dan Makna Kesejahteraan dalam Pandangan Islam.

Arsi, A., Fail, W. O. N., \& Arsyam, M. (2021, January 16). Membangun Keluarga Yang Islami. https://doi.org/10.31219/osf.io/43ygi

Makmur, Z., Arsyam, M., \& Alwi, A. M. S. (2020). Strategi Komunikasi Pembelajaran Di Rumah Dalam Lingkungan Keluarga Masa Pandemi. KOMUNIDA: Media Komunikasi dan Dakwah, 10(02), 231-241.

Humanika Musbikin, I., 2007, Membangun Rumah Tangga Sakinah, Cetakan II,

Yogyakarta: Mitra Pustaka.

Arsyam, M., \& Alwi, A. M. (2020). MANAJEMEN HIDUP DALAM PERSPEKTIF ALQUR'AN.

Zakirah, Z., Arsyam, M., HERIANTO, H., \& Umar, K. (2020, December 20). PENDIDIKAN DASAR (KUTTAB) MASA DAULAH ABBASIYAH $(132-232 \mathrm{H}$ / 750-847 M). https://doi.org/10.31219/osf.io/7t8bs

Bajri, M. (2018). Transformasi Ibadah Ritual Dalam Kehidupan Sosial. Elex Media Komputindo.

Sapada, A. O. (2020). Mendidik Anak Menjadi Anak Sholeh.

Adiwirawan, E. (2017). RELASI SPASIAL ANTARA KEGIATAN RITUAL IBADAH BERJAMAAH DENGAN ARSITEKTUR MESJID DI BANDUNG Studi kasus: Masjid Cipaganti, Masjid Salman, dan Masjid al Irsyad. Idealog: Ide dan Dialog Desain Indonesia, 2(1), 1-19.

Zakirah, Z., Arsyam, M., Altimory, \& H. (2020, November 3). Rekonstruksi Wacana Poligami Berbasis Nalar Fiqhi Kontemporer. https://doi.org/10.31219/osf.io/z8epm

Khoiruman, K. (2019). ASPEK IBADAH, LATIHAN SPRITUAL DAN AJARAN MORAL (Studi Pemikiran Harun Nasution tentang Pokok-Pokok Ajaran Islam). ElAfkar: Jurnal Pemikiran Keislaman dan Tafsir Hadis, 8(1), 39-60.

Sumarto, Y. (2019). Tinjauan Teologis Tentang Ibadah Bagi Pelaksanaan Misi Allah. Jurnal Jaffray, 17(1), 57-72. 